\title{
Sistem Pendukung Keputusan Pemilihan Sales Terbaik
}

\author{
Decision Support System for Best Sales Selection
}

\author{
Veny Cahya Hardita*1, Ema Utami ${ }^{2}$, Emha Taufiq Luthfi ${ }^{3}$ \\ 1,2,3 Magister Teknik Informatika, Universitas Amikom Yogyakarta \\ E-mail: *11 vencahya@gmail.com, ${ }^{2}$ ema@nrar.net, ${ }^{3}$ emhataufiqluthfi@amikom.ac.id
}

\begin{abstract}
Abstrak
Peran sales dalam sebuah perusahaan yaitu seseorang yang bertugas untuk melakukan tugas menawarkan, mendistribusikan dan mencari pesanan pelanggan yang berupa produk, termasuk juga mengumpulkan informasi tertentu dari para konsumen. Sehingga tugas sales ini sangat penting dalam pendapatan sebuah perusahaan. Dengan membuat apresiasi setiap bulan berupa tunjangan bonus setiap bulan yang hanya diberikan kepada sales terbaik, maka akan memberikan semangat para sales dalam melakukan promosi dan penjualan terhadap produk pada perusahaan tersebut. Dalam memberikan apresiasi diperlukan sebuah sistem pendukung keputusan untuk merangkingkan sales terbaik yang akan dipilih. Penelitian ini menggunakan metode Simple Additive Weighting (SAW) dan Technique for Order Preference by Similarity (TOPSIS). Metode ini dirasa mampu untuk merekomendasikan sales terbaik setiap bulannya pada suatu perusahaan. Hasil dari penelitian ini berupa rangking dan selanjutnya akan dibuat rekomendasi untuk sales terbaik yang akan dipilih. Hasil yang didapat pada penelitian menggunakan metode SAW TOPSIS yaitu alternatif C11 terpilih sebagai sales terbaik dengan nilai 0,650 sehingga menjadikan Afandi sales terbaik.
\end{abstract}

Kata Kunci - Sales, SAW, TOPSIS, Rangking

\begin{abstract}
The role of sales in a company is someone who is tasked with the task of offering, distributing and searching for customer's product order, this is include collecting certain information from customers. So the sales task is very important for earnings of company with monthly appreciation in the form of bonus allowance for the best sales, it is expected to encourage sales to promote and sell the company's product. In giving appreciation need a decision support system to rank the best sales to be chosen. This research will discuss about the implementation of Simple Additive Weighting (SAW) and Technique for Order Preference by Similarity (TOPSIS) method. This method is considered capable of recommending the best sales every month for a company. The results of this research are in the form of ranking and recommendations will then be made for the best sales to be selected. The research result using SAW and TOPSIS method is the alternative C11 is choose as the best sales with score 0.650 and made Affandi as the best sales.
\end{abstract}

Keywords — Sales, SAW, TOPSIS, Ranking

\section{PENDAHULUAN}

PT Eratel Prima Palangkaraya merupakan perusahaan yang bergerak pada bidang distribusi produk memiliki tugas sebagai perantara suatu produk kepada konsumen. Perusahaan ini menitik beratkan produk tersebut sebagai penghasilan utama mereka. Dalam memasarkannya pun diperlukan seorang perantara yang dapat mengenalkan produk apa yang akan dipasarkan. 
Sales perusahaan sangat berpengaruh penting dalam meningkatkan penjualan produk, karena sales merupakan ujung tombak perusahaan. Sales bertugas untuk melakukan kegiatan menawarkan, mendistribusikan, dan mencari pesanan penjualan atas produk dan jasa, termasuk menyampaikan dan mengumpulkan informasi tertentu dari para agen atau konsumen. Sebagai ujung tombak perusahaan, tentu sangat penting untuk memelihara semangat serta konsistensi seorang sales. Oleh sebab itu, untuk memberikan semangat pada sales dalam menjalankan target penjualan, sebuah perusahaan membuat apresiasi untuk sales terbaik setiap bulannya berdasarkan kriteria-kriteria yang ditetapkan. Pemberian apresiasi kepada sales membutuhkan penilaian yang objektif, jujur, serta adil agar seluruh sales bekerja dengan optimal, namun dalam fakta lapangan, penilaian terhadap individu tidak lepas dari faktor subjektif sehingga akan memberikan dampak negatif kepada pihak manajemen perushaan maupun antar sales itu sendiri.

Karena itu, dibutuhkan suatu sistem penilaian yang dapat melakukan penilaian secara objektif dan adil serta sesuai dengan kriteria-kriteria yang telah ditentukan untuk menghasilkan suatu keputusan sales terbaik yang terpilih. Parameter dikatakan sales tersebut layak mendapatkan predikat terbaik adalah ketika nilai semua kriterianya melebihi standar yang ditetapkan. Banyak metode yang dapat digunakan dalam membangun sistem pemilihan sales terbaik, salah satunya dengan metode Simple Additive Weighting (SAW) dan Technique for order preference by similarity to ideal solution (TOPSIS) yang dapat digunakan untuk menyelesaikan masalah.

Sistem pemilihan sales terbaik ini akan meningkatkan optimalisasi dalam penentuan sales yang layak diberikan benefit atau bonus setiap bulan apabila saes tersebut menjadi sales terbaik. Metode yang digunakan yaitu menggabungkan metode SAW dan TOPSIS. Metode SAW sering juga dikenal istilah metode penjumlahan terbobot. Konsep dasar metode SAW adalah mencari penjumlahan terbobot dari rating kinerja pada setiap alternatif pada semua atribut. Metode SAW membutuhkan proses normalisasi matriks keputusan (X) ke suatu skala yang dapat dibandingkan dengan semua rating alternatif yang ada. Sedangkan metode TOPSIS menggunakan prinsip bahwa alternatif yang terpilih harus mempunyai jarak terdekat dari solusi ideal posistif dan terjauh dari solusi ideal negatif dari sudut pandang geometris dengan menggunakan jarak Euclidean untuk menentukan kedekatan relatif dari suatu alternatif dengan solusi optimal.

Beberapa penelitian yang telah dilakukan sebelumnya menjadi referensi dalam penelitian ini, yaitu: Penilitian dengan judul "Penerapan Metode SAW dan Fuzzy Dalam Sistem Pendukung bertujuan Keputusan Penerimaan Beasiswa” membantu KaProdi Teknik Informatika maupun Prodi-Prodi lain di UNP kediri untuk menentukan penerima beasiswa. Penelitian ini bertujuan untuk memadukan metode Fuzzy dan SAW dengan ketentuan dan kriteria yang sudah ditentukan oleh pihak Universitas [1].

Penelitian dengan judul "Sistem Pendukung Keputusan Pemilihan Dosen Berprestasi Di STMIK Tasikmalaya Menggunakan Metode Simple Additive Weighting (SAW)” bertujuan untuk merancang sebuah sistem pendukung keputusan untuk pemilihan dosen berprestasi menggunakan Metode Simple Additive Weighting (SAW). Adapun kriteria yang dipakai yaitu: Penilaian Mahasiswa, Penilaian Dosen sejawat, Penilaian Pimpinan/Manajemen, Kualifikasi Akademik, Penelitian, Jurnal, Pelatihan, Seminar, Pengabdian kepada Masyarakat, dan Jabatan Akademik. Dalam penelitian ini alat bantu perancangan sistemnya menggunakan Diagram Arus Data (DAD), sedangkan teknik perancangan basis datanya menggunakan ERD. Hasil akhir dari penelitian ini didapatkan metode SAW mampu mengatasi permasalahan dalam memilih dosen berprestasi di STMIK Tasikmalaya [2].

Penelitian dengan judul "Sistem Pendukung Keputusan Untuk Menentukan Prestasi Akademik Siswa dengan Metode TOPSIS” yang membahas tentang penentuan keputusan dalam menentukan siswa yang memiliki prestasi terbaik. Kepala sekolah seharusnya mengambil sebuah keputusan berdasarkan perhitungan dan pemikiran jangka panjang agar keputusan menentukan prestasi akademik siswa yang akan diambil tidak salah. Di MA Darul Masholeh masih terdapat masalah dalam membuat laporan pembelajaran siswa, untuk menentukan siswa yang berprestasi hanya ditentukan menggunakan nilai rapot, belum adanya pemanfaatan secara optimal data laporan penilaian hasil belajar siswa, masih adanya kesulitan untuk mengetahui pencapaian dari kegiatan pembelajaran siswa. Dengan menggunakan metode TOPSIS dapat mempermudah guru 
untuk menentukan prestasi akademik siswasecara tepat dan cepat, dimana metode TOPSIS adalah salah satu metode pengambilan keputusan dimana alternatif yang terpilih merupakan alternatif terbaik yang mempunyai jarak terdekat dari solusi ideal positif dan terjauh dari solusi ideal negatif. Dari pengujian 20 alternatif dengan 6 kriteria yaitu hafalan al-qur'an, nilai rata-rata rapot, absensi, nilai minimal, total nilai dan piagam prestasi. Dari 20 alternatif di dapatkan siswa yang berprestasi yaitu diurutan pertama Wildan dengan nilai preferensi relative 0,66, Kedua Ratna $(0,64)$, ketiga Sinta $(0,55)$, keempat Rini $(0,50)$, Kelima Faisal $(0,38)$ dan terakhir Sadriyah dengan nilai preferensi relative $(0,00)[3]$.

Penelitian dengan judul "Sistem Pendukung Keputusan Pemilihan Ketua Program Studi Berprestasi Menggunakan Metode TOPSIS” membahas tentang Sistem pemberian penghargaan dapat mendorong Ketua Program Studi untuk lebih berprestasi dan produktif, sehingga tujuan pengembangan sistem pendidikan tinggi dan pembangunan nasional pada umumnya dapat tercapai secara optimal. Pemberian penghargaan ini dilakukan secara rutin oleh kemenristekdikti tiap tahun. Menentukan Ketua Program Studi Berprestasi menggunakan Sistem Pendukung Keputusan (SPK). SPK dibuat dengan beberapa tahapan dimulai dari studi literature, desain sistem, membangun sistem dengan menerapkan metode TOPSIS dalam SPK, implementasi dan pengujian sistem, dan analisis sistem yang telah dibangun. Sistem Pendukung Keputusan ini dapat digunakan untuk mempermudah serta membantu dalam menentukan Ketua Program Studi Berprestasi [4] .

Dari beberapa penelitian tersebut peneliti mencoba untuk menggabungkan metode SAW dan TOPSIS dalam memilih sales terbaik pada PT. Eratel Prima Palangkaraya.

\section{METODE PENELITIAN}

\subsection{Alur Penelitian}

Penelitian yang akan dilakukan adalah menerapkan metode SAW dan TOPSIS dalam pemilihan sales terbaik. Alur penelitian dijelaskan pada Gambar 1.

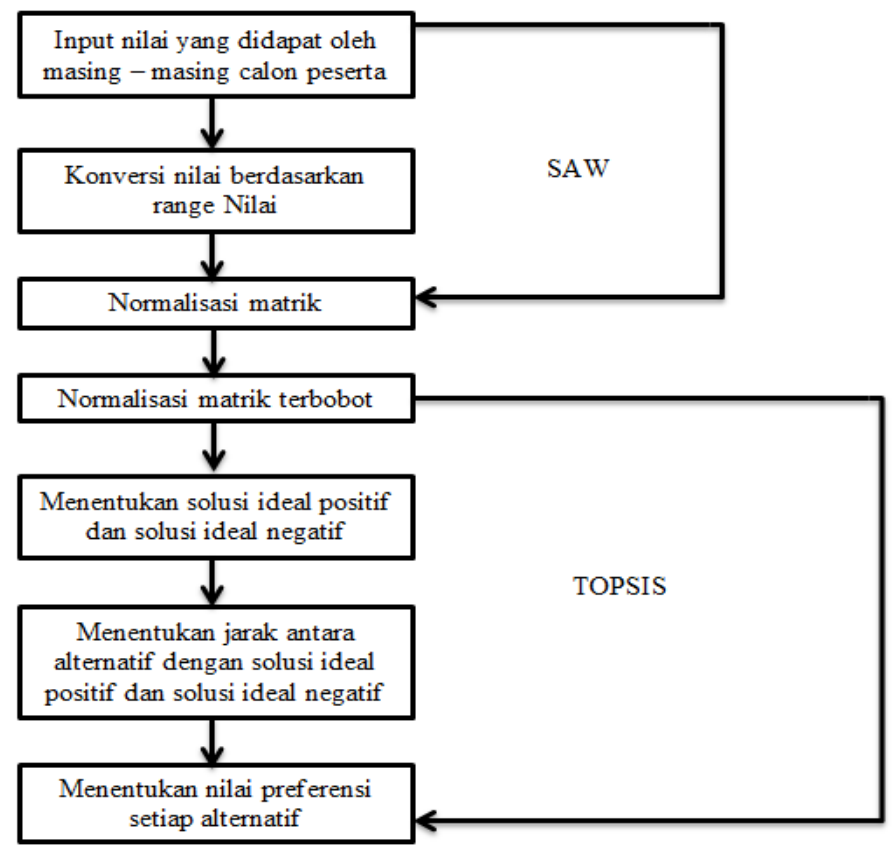

Gambar 1. Alur Penelitian

Pada Gambar 1 melakukan normalisasi dengan metode SAW yang kemudian normalisasi bobot hingga proses perangkingan dilakukan menggunakan metode TOPSIS. 
Citec Journal, Vol. 5, No. 2, Februari 2018 - April 2018

\subsection{Analisis Kriteria}

Proses perhitungan pemilihan sales dilakukan berdasarkan kriteria yang telah ditentukan dan setiap kriteria memiliki bobot perhitungan. Pada penilaian sales terbaik PT. Eratel Prima Palangkaraya didapatkan 5 (lima) kriteria yang menjadi acuan dalam pengambilan keputusan, yaitu:

1. Penjualan Perdana

Penjualan perdana didapatkan dari jumlah penjualan perdana (SP) sales tiap bulannya. Jumlah penjualan perdana ini merupakan poin penting yang digunakan untuk menilai penjualan sales.

2. Penjualan Voucher

Sama halnya dengan penjualan perdana, penjualan voucher juga didapatkan dari jumlah penjualan voucher setiap bulannya.

3. Pelayanan

Penilaian pelayanan didasarkan pada pelayanan sales tersebut ketika melakukan kunjungan outlet.

4. Perilaku

Penilaian perilaku didasarkan pada tingkah laku sales sehari-hari.

5. Absen

Absensi didapatkan dari absen sales setiap bulan.

Tabel 1 berikut merupakan tabel penilaian kriteria pemilihan sales terbaik pada perusahaan provider.

Tabel 1. Tabel Penilaian Kriteria

\begin{tabular}{|c|c|c|c|}
\hline Kriteria & Nilai & $\begin{array}{c}\text { Tingkat } \\
\text { Kepentingan / } \\
\text { Bobot }\end{array}$ & $\begin{array}{c}\text { Nilai } \\
\text { Konversi }\end{array}$ \\
\hline Penjualan Perdana & & 5 & \\
\hline Penjualan Voucher & & 5 & \\
\hline \multirow{5}{*}{ Pelayanan } & Sangat Buruk & \multirow{5}{*}{3} & 1 \\
\hline & Buruk & & 2 \\
\hline & Cukup & & 3 \\
\hline & Baik & & 4 \\
\hline & Sangat Baik & & 5 \\
\hline \multirow{5}{*}{ Perilaku } & Sangat Buruk & \multirow{5}{*}{3} & 1 \\
\hline & Buruk & & 2 \\
\hline & Cukup & & 3 \\
\hline & Baik & & 4 \\
\hline & Sangat Baik & & 5 \\
\hline \multirow{5}{*}{ Absen } & Sangat Buruk & \multirow{5}{*}{4} & 1 \\
\hline & Buruk & & 2 \\
\hline & Cukup & & 3 \\
\hline & Baik & & 4 \\
\hline & Sangat Baik & & 5 \\
\hline
\end{tabular}

\subsection{Simple Additive Weighting (SAW)}

Simple Additive Weighting merupakan model dari penjumlahan berbobot. Pendekatan SAW yakni mencari penjumlahan terbobot dari rating kinerja seluruh alternatif pilihan pada semua atribut [5].

Berikut merupakan langkah penyelesaian dengan menggunakan metode SAW [5]:

1. Menentukan Ci yang merupakan kriteria saja yang akan dijadikan acuan dalam pengambilan keputusan. 
2. Menentukan rating kecocokan setiap alternatif pada setiap kriteria.

3. Membuat matriks keputusan berdasarkan (Ci), kemudian kemudian melakukan normalisasi matriks berdasarkan persamaan yang disesuaikan dengan jenis atribut (atribut keuntungan ataupun atribut biaya) sehingga diperoleh matriks ternormalisasi R. rumus yang digunakan untuk melakukan normalisasi adalah seperti persamaan 1.

$$
r_{i j}\left\{\begin{array}{l}
\frac{x_{i j}}{\max x_{i j}} j i k a j \text { adalah atribut keuntungan (benefit) } \\
\frac{\min x_{i j}}{x_{i j}} \text { jika j adalah atribut biaya }(\text { cost) }
\end{array}\right.
$$

Keterangan:

$r_{i j} \quad$ : rating kinerja ternormalisasi

max $_{i j} \quad$ : nilai maksimum dari setiap baris dan kolom

$\min _{i j} \quad$ : nilai minimum dari setiap baris dan kolom

$x_{i j} \quad$ : baris dan kolom dari matriks

4. Hasil akhir diperoleh dari proses perankingan yaitu penjumlahan dari perkalian matriks ternormalisasi $\mathrm{R}$ dengan vektor bobot sehingga diperoleh nilai terbesar yang dipilih sebagai alternatif terbaik (Ai) sebagai solusi. rij adalah rating kinerja ternormalisasi dari alternatif $\mathrm{Ai}$ pada atribut $C_{j}, i=1,2 \ldots m$ dan $j=1,2 \ldots$, n. Nilai preferensi untuk setiap alternatif $\left(V_{i}\right)$ diberikan seperti pada persamaan 2:

Keterangan:

$$
v_{i} \sum_{j=1}^{n} w_{j} r_{i j}
$$

$v_{i} \quad$ : Nilai akhir dari alternatif

$w_{j} \quad$ : Bobot yang telah ditentukan

$r_{i j} \quad$ : Normalisasi matriks

\subsection{Technique for Order Preference by Similarity (TOPSIS)}

TOPSIS merupakan salah satu metode yang dapat membantu untuk pengambilan sebuah keputusan dalam menyelesaikan beberapa masalah. Metode memberikan solusi perangkingan berdasarkan prioritas nilai kedekatan relatif suatu alternatif terhadap solusi ideal positif [5].

Berikut adalah langkah - langkah metode TOPSIS [5] [6]:

a) Menentukan matriks solusi ideal positif dan solusi ideal negatif.

Solusi ideal positif dinotasikan A+, sedangkan solusi ideal negatif dinotasikan A-. Berikut ini adalah persamaan 3 dan persamaan 4 dari A+ dan A-:

$$
\begin{aligned}
\mathrm{A}^{+}= & \left\{\left(\max v_{i j} \mid \mathrm{j} € \mathrm{~J}\right),\left(\min v_{i j} \mid \mathrm{j} € \mathrm{~J}\right), \mathrm{i}=1,2,3, \ldots, \mathrm{m}\right\} \\
& =\left\{v_{1}{ }^{+}, v_{2}^{+}, v_{3}^{+}, \ldots, v_{\mathrm{n}}^{+},\right\} \\
\mathrm{A}^{-}= & \left\{\left(\min v_{i j} \mid \mathrm{j} € \mathrm{~J}\right),\left(\max v_{i j} \mid \mathrm{j} € \mathrm{~J}\right), \mathrm{i}=1,2,3, \ldots, \mathrm{m}\right\} \\
= & \left\{v_{1}^{-}, v_{2}^{-}, v_{3}^{-}, \ldots ., v_{\mathrm{n}}^{-},\right\}
\end{aligned}
$$

$\mathrm{J}=\{\mathrm{j}=1,2,3, \ldots, \mathrm{n}$ dan $\mathrm{J}$ merupakan himpunan kriteria keuntungan (benefit criteria) $\}$.

$J^{\prime}=\{\mathrm{j}=1,2,3, \ldots, \mathrm{n}$ dan J' merupakan himpunan kriteria biaya (cost criteria) $\}$

Keterangan:

$v_{i j}$ adalah elemen dari matriks keputusan yang ternormalisasi terbobot $\mathrm{V}$,

$v_{j}^{+}(\mathrm{j}=1,2,3, \ldots, \mathrm{n})$ adalah elemen matriks solusi ideal positif,

$v_{j}^{-}(\mathrm{j}=1,2,3, \ldots, \mathrm{n})$ adalah elemen matriks solusi ideal negatif. 
Citec Journal, Vol. 5, No. 2, Februari 2018 - April 2018

ISSN: 2460-4259

b) Menghitung separasi.

$S^{+}$adalah jarak alternatif dari solusi ideal positif didefenisikan sebagai persamaan 5.

$$
S i^{+}=\sqrt{\sum_{j=1}^{n}\left(v_{i j}-v_{j}^{+}\right)^{2}} \text {, dengan } \mathrm{i}=1,2,3, \ldots, \mathrm{m}
$$

$S^{\circledR}$ adalah jarak alternatif dari solusi ideal negatif didefenisikan sebagai persamaan 6 .

$$
S i^{-}=\sqrt{\sum_{j=1}^{n}\left(v_{i j}-v_{j}^{-}\right)^{2}} \text {, dengan } \mathrm{i}=1,2,3, \ldots, \mathrm{m}
$$

\section{Keterangan:}

$\mathrm{Si}^{+}$adalah jarak alternatif ke-I dari solusi ideal positif,

$\mathrm{Si}^{-}$adalah jarak alternatif ke-I dari solusi ideal negatif,

$v_{i j}$ adalah elemen dari matriks keputusan yang ternormalisasi terbobot $\mathrm{V}$,

$v_{j}^{+}$adalah elemen matriks solusi ideal positif,

$v_{j}^{-}$adalah elemen matriks solusi ideal negatif.

c) Mencari nilai prefernsi pada setiap alternatif.

Mencari nilai prefernsi pada setiap alternatif dapat dihitung dengan menggunakan persamaan 7 berikut.

$$
\begin{aligned}
& c_{i}^{+}=\frac{s_{i}{ }^{-}}{s_{i}{ }^{-}+s_{i}{ }^{+}}, 0 \leq c_{i}{ }^{+} \leq 1 \\
& \text { dengan } \mathrm{i}=1,2,3, \ldots, \mathrm{m}
\end{aligned}
$$

keterangan:

$c_{i}{ }^{+}$adalah kedekatan relatif dari alternatif ke-I tehadap solusi ideal positif,

$s_{i}{ }^{+}$adalah jarak alternatif ke-I dari solusi ideal positif,

$s_{i}{ }^{-}$adalah jarak alternatif ke-I dari solusi ideal negatif.

d) Merangking aternatif.

Alternatif diurutkan dari nilai $\mathrm{C}+$ terbesar ke nilai terkecil. Alternatif dengan nilai $\mathrm{C}+$ terbesar merupakan solusi terbaik.

\section{HASIL DAN PEMBAHASAN}

\subsection{Hasil Perhitungan}

Alternatif dalam penentuan sales terbaik mengambil 20 sampel dari penilaian sales yang akan dihitung dengan menggunakan metode TOPSIS. Tahapan perhitungan metode TOPSIS adalah sebagai berikut.

1. Membangun sebuah matriks keputusan

Tabel 2 berikut merupakan tabel nilai alternatif terhadap masing-masing kriteria yang dapat digunakan sebagai matriks keputusan alternatif.

Tabel 2. Tabel Nilai Alternatif Terhadap Kriteria

\begin{tabular}{|c|c|c|c|c|c|c|}
\hline No & Nama Sales & $\begin{array}{c}\text { Penjualan } \\
\text { Perdana (SP) }\end{array}$ & $\begin{array}{c}\text { Penjualan } \\
\text { Voucher }\end{array}$ & Pelayanan & Perilaku & Absen \\
\hline 1 & Raka & 589 & 87 & 4 & 5 & 5 \\
\hline 2 & Alif & 487 & 90 & 4 & 3 & 5 \\
\hline 3 & Surya & 330 & 100 & 5 & 4 & 4 \\
\hline 4 & Wilis & 234 & 110 & 4 & 5 & 4 \\
\hline
\end{tabular}




\begin{tabular}{|c|c|c|c|c|c|c|}
\hline No & Nama Sales & $\begin{array}{c}\text { Penjualan } \\
\text { Perdana (SP) }\end{array}$ & $\begin{array}{c}\text { Penjualan } \\
\text { Voucher }\end{array}$ & Pelayanan & Perilaku & Absen \\
\hline 5 & Yazid & 567 & 121 & 4 & 4 & 4 \\
\hline 6 & Yunus & 343 & 101 & 4 & 5 & 5 \\
\hline 7 & Riki & 230 & 120 & 4 & 5 & 5 \\
\hline 8 & Ariga & 300 & 120 & 5 & 5 & 5 \\
\hline 9 & Fahmi & 590 & 130 & 4 & 2 & 3 \\
\hline 10 & Amin & 340 & 210 & 4 & 3 & 5 \\
\hline 11 & Afandi & 333 & 220 & 5 & 4 & 5 \\
\hline 12 & Faris & 423 & 99 & 5 & 4 & 5 \\
\hline 13 & Setyo & 400 & 141 & 4 & 5 & 4 \\
\hline 14 & Ilham & 200 & 102 & 5 & 3 & 4 \\
\hline 15 & Diky & 343 & 109 & 5 & 5 & 4 \\
\hline 16 & Vasha & 450 & 176 & 3 & 4 & 5 \\
\hline 17 & David & 400 & 198 & 3 & 3 & 3 \\
\hline 18 & Ray & 430 & 209 & 2 & 3 & 4 \\
\hline 19 & Okta & 330 & 116 & 4 & 5 & 5 \\
\hline 20 & Hardi & 450 & 122 & 4 & 5 & 4 \\
\hline
\end{tabular}

2. Membangun matriks ternormalisasi

Untuk menyelesaikan masalah di atas menggunakan metode Simple Additive Weighting, maka dilakukan normalisasi matriks X.

$$
r_{11}: \frac{589}{\max (589,487,330,234,567,343,230,300,590,340,333,423,400,200,343,450,400,430,330,450)}=0998
$$

Dan seterusnya hingga didapat hasil mastriks normalisasi seperti pada Tabel 3.

Tabel 3. Hasil Perhitungan Normalisasi Kriteria dengan SAW

\begin{tabular}{|c|c|c|c|c|}
\hline Normalisasi K1 & Normalisasi K2 & Normalisasi K3 & Normalisasi K4 & Normalisasi K5 \\
\hline 0,998 & 0,395 & 0,800 & 1,000 & 1,000 \\
\hline 0,825 & 0,409 & 0,800 & 0,600 & 1,000 \\
\hline 0,559 & 0,455 & 1,000 & 0,800 & 0,800 \\
\hline 0,397 & 0,500 & 0,800 & 1,000 & 0,800 \\
\hline 0,961 & 0,550 & 0,800 & 0,800 & 0,800 \\
\hline 0,581 & 0,459 & 0,800 & 1,000 & 1,000 \\
\hline 0,390 & 0,545 & 0,800 & 1,000 & 1,000 \\
\hline 0,508 & 0,545 & 1,000 & 1,000 & 1,000 \\
\hline 1,000 & 0,591 & 0,800 & 0,400 & 0,600 \\
\hline 0,576 & 0,955 & 0,800 & 0,600 & 1,000 \\
\hline 0,564 & 1,000 & 1,000 & 0,800 & 1,000 \\
\hline 0,717 & 0,450 & 1,000 & 0,800 & 1,000 \\
\hline 0,678 & 0,641 & 0,800 & 1,000 & 0,800 \\
\hline 0,339 & 0,464 & 1,000 & 0,600 & 0,800 \\
\hline 0,581 & 0,495 & 1,000 & 1,000 & 0,800 \\
\hline 0,763 & 0,800 & 0,600 & 0,800 & 1,000 \\
\hline 0,678 & 0,900 & 0,600 & 0,600 & 0,600 \\
\hline 0,729 & 0,950 & 0,400 & 0,600 & 0,800 \\
\hline 0,559 & 0,527 & 0,800 & 1,000 & 1,000 \\
\hline 0,763 & 0,555 & 0,800 & 1,000 & 0,800 \\
\hline
\end{tabular}


Citec Journal, Vol. 5, No. 2, Februari 2018 - April 2018

ISSN: 2460-4259

3. Membuat matriks keputusan yang ternormalisasi terbobot

Menghitung ternormalisasi terbobot yaitu dengan cara bobot kriteria yang sudah ditentukan dikalikan dengan nilai normalisasi. Bobot yang telah ditentukan adalah seperti pada Tabel 4.

Tabel 4. Tabel Bobot dari Kriteria

\begin{tabular}{|c|l|c|}
\hline No & \multicolumn{1}{|c|}{ Kriteria } & Bobot (W) \\
\hline 1 & Penjualan Perdana & 5 \\
\hline 2 & Penjualan Voucher & 5 \\
\hline 3 & Pelayanan & 3 \\
\hline 4 & Perilaku & 3 \\
\hline 5 & Absen & 4 \\
\hline
\end{tabular}

Perkalian bobot normalisasi ditunjukan pada Tabel 5.

Tabel 5. Menghitung Bobot Normalisasi

\begin{tabular}{|c|c|c|c|c|}
\hline Normalisasi K1 & Normalisasi K2 & Normalisasi K3 & Normalisasi K4 & Normalisasi K5 \\
\hline $0,998 * 5=4,99$ & $0,395 * 5=1,98$ & $0,800 * 3=2,4$ & $1,000 * 3=3$ & $1,000 * 4=4$ \\
\hline $0,825 * 5=4,13$ & $0,409 * 5=2,05$ & $0,800 * 3=2,4$ & $0,600 * 3=1,8$ & $1,000 * 4=4$ \\
\hline $0,559 * 5=2,80$ & $0,455 * 5=2,27$ & $1,000 * 3=3$ & $0,800 * 3=2,4$ & $0,800 * 4=$ \\
\hline $0,397 * 5=1,98$ & $0,500 * 5=2,50$ & $0,800 * 3=2,4$ & $1,000 * 3=3$ & $0,800 * 4=3,2$ \\
\hline $0,961 * 5=4,81$ & $0,550 * 5=2,75$ & $0,800 * 3=2,4$ & $0,800 * 3=2,4$ & $0,800 * 4=3,2$ \\
\hline $0,581 * 5=2,91$ & $0,459 * 5=2,30$ & $0,800 * 3=2,4$ & $1,000 * 3=3$ & $1,000 * 4=4$ \\
\hline $0,390 * 5=1,95$ & $0,545 * 5=2,73$ & $0,800 * 3=2,4$ & $1,000 * 3=3$ & $1,000 * 4=4$ \\
\hline $0,508 * 5=2,54$ & $0,545 * 5=2,73$ & $1,000 * 3=3$ & $1,000 * 3=3$ & $1,000 * 4=4$ \\
\hline $1,000 * 5=5$ & $0,591 * 5=2,95$ & $0,800 * 3=2,4$ & $0,400 * 3=1,2$ & $0,600 * 4=2,4$ \\
\hline $0,576 * 5=2,88$ & $0,955 * 5=4,77$ & $0,800 * 3=2,4$ & $0,600 * 3=1,8$ & $1,000 * 4=4$ \\
\hline $0,564 * 5=2,82$ & $1,000 * 5=5$ & $1,000 * 3=3$ & $0,800 * 3=2,4$ & $1,000 * 4=4$ \\
\hline $0,717 * 5=3,58$ & $0,450 * 5=2,25$ & $1,000 * 3=3$ & $0,800 * 32,4$ & $1,000 * 4=4$ \\
\hline $0,678 * 5=3,39$ & $0,641 * 5=3,20$ & $0,800 * 3=2,4$ & $1,000 * 3=3$ & $0,800 * 4=3,2$ \\
\hline $0,339 * 5=1,69$ & $0,464 * 5=2,32$ & $1,000 * 3=3$ & $0,600 * 3=1,8$ & $0,800 * 4=3,2$ \\
\hline $0,581 * 5=2,91$ & $0,495 * 5=2,48$ & $1,000 * 3=3$ & $1,000 * 3=3$ & $0,800 * 4=3,2$ \\
\hline $0,763 * 5=3,81$ & $0,800 * 5=4$ & $0,600 * 3=1,8$ & $0,800 * 3=2,4$ & $1,000 * 4=4$ \\
\hline $0,678 * 5=3,39$ & $0,900 * 5=4,50$ & $0,600 * 3=1,8$ & $0,600 * 3=1,8$ & $0,600 * 4=2,4$ \\
\hline $0,729 * 5=3,64$ & $0,950 * 5=4,75$ & $0,400 * 3=1,2$ & $0,600 * 3=1,8$ & $0,800 * 4=3,2$ \\
\hline $0,559 * 5=2,80$ & $0,527 * 5=2,64$ & $0,800 * 3=2,4$ & $1,000 * 3=3$ & $1,000 * 4=4$ \\
\hline $0,763 * 5=3,81$ & $0,555 * 5=2,77$ & $0,800 * 3=2,4$ & $1,000 * 3=3$ & $0,800 * 4=3,2$ \\
\hline
\end{tabular}

4. Menentukan matriks solusi dari ideal positif dan solusi ideal negative

Solusi ideal positif yaitu sebagai berikut:

$\mathrm{A}^{+}=\max \{4,99 ; 4,13 ; 2,8 ; 1,98 ; 4,81 ; 2,91 ; 1,95 ; 2,54 ; 5 ; 2,88 ; 2,82 ; 3,58 ; 3,39$; $1,69 ; 2,91 ; 3,81 ; 3,39 ; 3,64 ; 2,8 ; 3,81\}$

$$
=5
$$

$\mathrm{A}^{+}=5$

$\mathrm{A}^{+}=3$

$\mathrm{A}^{+}=3$

$\mathrm{A}^{+}=4$ 
Solusi ideal negatif yaitu sebagai berikut:

$\mathrm{A}^{-}=\min \{4,99 ; 4,13 ; 2,8 ; 1,98 ; 4,81 ; 2,91 ; 1,95 ; 2,54 ; 5 ; 2,88 ; 2,82 ; 3,58 ; 3,39$; $1,69 ; 2,91 ; 3,81 ; 3,39 ; 3,64 ; 2,8 ; 3,81\}$

$=1,69$

$\mathrm{A}^{-}=1,98$

A3- $=1,2$

A4- $=1,2$

A5- $=2,4$

Sehingga diperoleh tabel solusi ideal positif dan solusi ideal negatif seperti pada tabel 6 .

Tabel 6. Tabel Solusi Ideal Positif dan Solusi Ideal Negatif

\begin{tabular}{|l|c|c|c|c|c|}
\hline & A1 & A2 & A3 & A4 & A5 \\
\hline Solusi ideal postif & 5 & 5 & 3 & 3 & 4 \\
\hline Solusi ideal negatif & 1,69 & 1,98 & 1,2 & 1,2 & 2,4 \\
\hline
\end{tabular}

5. Menghitung separasi

Langkah berikutnya adalah menghitung separasi (jarak) alternatif dari solusi ideal postif dan solusi ideal negatif. Perhitungan separasi adalah sebagai berikut:

Perhitungan separasi ideal positif:

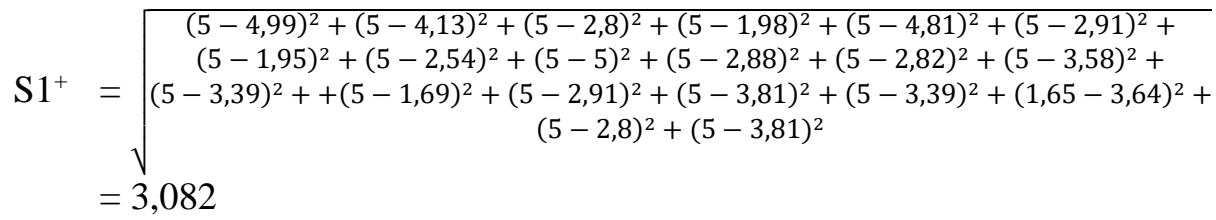

Dan seterusnya hingga pada perhitungan separasi ideal positif $\mathrm{S} 20^{+}$.

Perhitungan separasi ideal negatif:

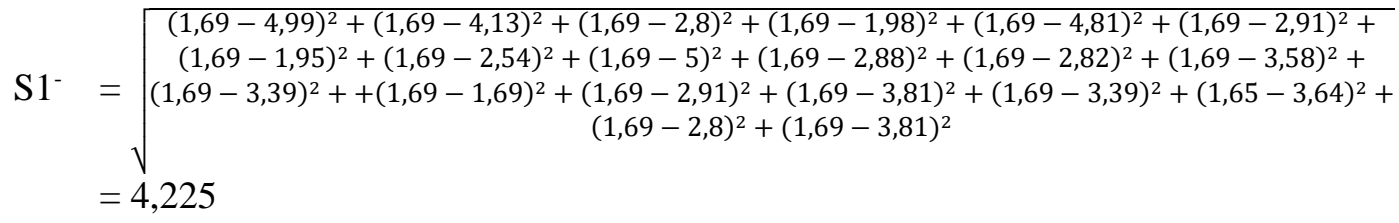

Dan seterusnya hingga separasi solusi ideal negatif S10-. Tabel 7 merupakan tabel hasil separasi solusi ideal positif dan solusi ideal negatif.

Tabel 7. Tabel Separasi Solusi Ideal Positif dan Separasi Solusi Ideal Negatif

\begin{tabular}{|l|l|l|l|}
\hline S1+ & 3,082 & S1- & 4,255 \\
\hline S2+ & 3,360 & S2- & 3,206 \\
\hline S3+ & 3,646 & S3- & 2,573 \\
\hline S4+ & 4,044 & S4- & 2,382 \\
\hline S5+ & 2,542 & S5- & 3,714 \\
\hline S6+ & 3,472 & S6- & 2,968 \\
\hline S7+ & 3,851 & S7- & 2,805 \\
\hline S8+ & 3,347 & S8- & 3,213 \\
\hline S9+ & 3,216 & S9- & 3,649 \\
\hline S10+ & 2,518 & S10- & 3,685 \\
\hline S11+ & 2,259 & S11- & 4,201 \\
\hline
\end{tabular}


Citec Journal, Vol. 5, No. 2, Februari 2018 - April 2018

\begin{tabular}{|l|l|l|l|} 
S12+ & 3,150 & S12- & 3,299 \\
\hline S13+ & 2,611 & S13- & 3,114 \\
\hline S14+ & 4,494 & S14- & 2,087 \\
\hline S15+ & 3,374 & S15- & 2,973 \\
\hline S16+ & 2,051 & S16- & 3,597 \\
\hline S17+ & 2,878 & S17- & 3,155 \\
\hline S18+ & 2,687 & S18- & 3,534 \\
\hline S19+ & 3,287 & S19- & 2,981 \\
\hline S20+ & 2,714 & S20- & 3,231 \\
\hline
\end{tabular}

6. Mencari nilai preferensi pada setiap alternatif

Dalam mencari nilai preferensi setiap alternatif maka membagi nilai separasi solusi ideal negatif dengan penjumlahan separasi solusi ideal negatif dan separasi solusi ideal positif. Hasil nilai preferensi terbesar merupakan hasil yang akan dipilih.

$\mathrm{C} 1=4,255 /(4,255+3,082)=0,546$

$\mathrm{C} 2=3,206 /(3,206+3,360)=0,459$

Perhitungan seterusnya sampai C20 hingga diperoleh hasil seperti pada Tabel 8.

Tabel 8. Nilai Preferensi

\begin{tabular}{|l|r|}
\hline C1 & 0,580 \\
\hline C2 & 0,488 \\
\hline C3 & 0,414 \\
\hline C4 & 0,371 \\
\hline C5 & 0,594 \\
\hline C6 & 0,461 \\
\hline C7 & 0,421 \\
\hline C8 & 0,490 \\
\hline C9 & 0,532 \\
\hline C10 & 0,594 \\
\hline C11 & 0,650 \\
\hline C12 & 0,512 \\
\hline C13 & 0,544 \\
\hline C14 & 0,317 \\
\hline C15 & 0,468 \\
\hline C16 & 0,637 \\
\hline C17 & 0,523 \\
\hline C18 & 0,568 \\
\hline C19 & 0,476 \\
\hline C20 & 0,543 \\
\hline
\end{tabular}

Nilai preferensi terbesar adalah C11 bernilai 0,650, maka Afandi merupakan sales terbaik yang terpilih. 


\subsection{Hasil Sistem}

a. Halaman Utama (Dashboard)

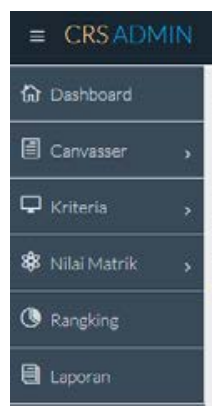

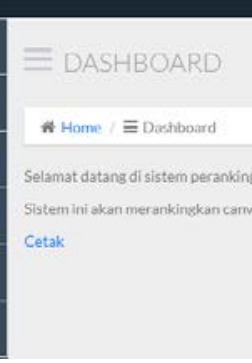

Gambar 2. Halaman Utama

Pada Gambar 2 menunjukkan tampilan untuk halaman utama sistem. Halaman utama berisi tentang penjelasan sistem.

b. Halaman Kriteria

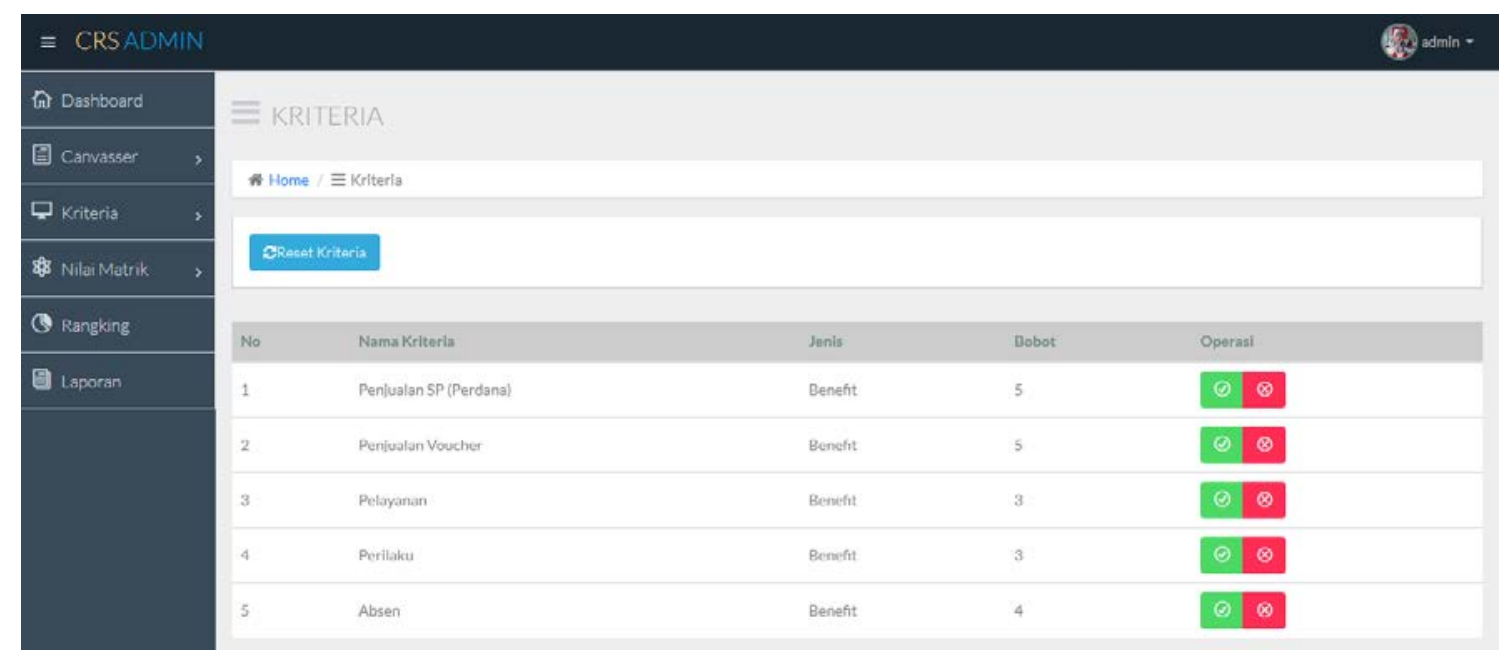

Gambar 3. Halaman Kriteria

Pada Gambar 3 merupakan halaman kriteria, kriteria dapat diubah atau ditambah sesuai dengan keinginan User. 
Citec Journal, Vol. 5, No. 2, Februari 2018 - April 2018

ISSN: 2460-4259

c. Halaman Nilai Matrik

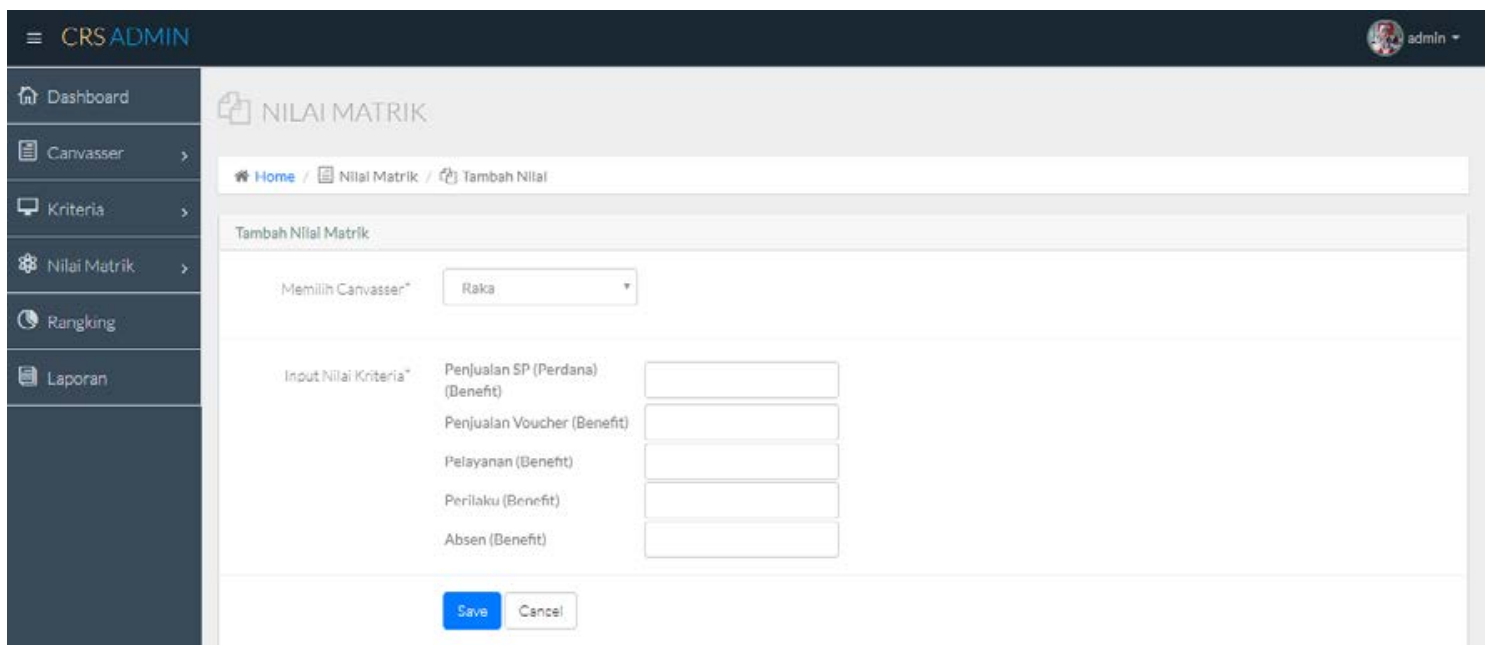

Gambar 4. Halaman Nilai Matrik

Nilai matrik pada Gambar 5 yang telah diinputkan dapat dilihat pada menu halaman detail nilai matrik.

d. Halaman Ranking
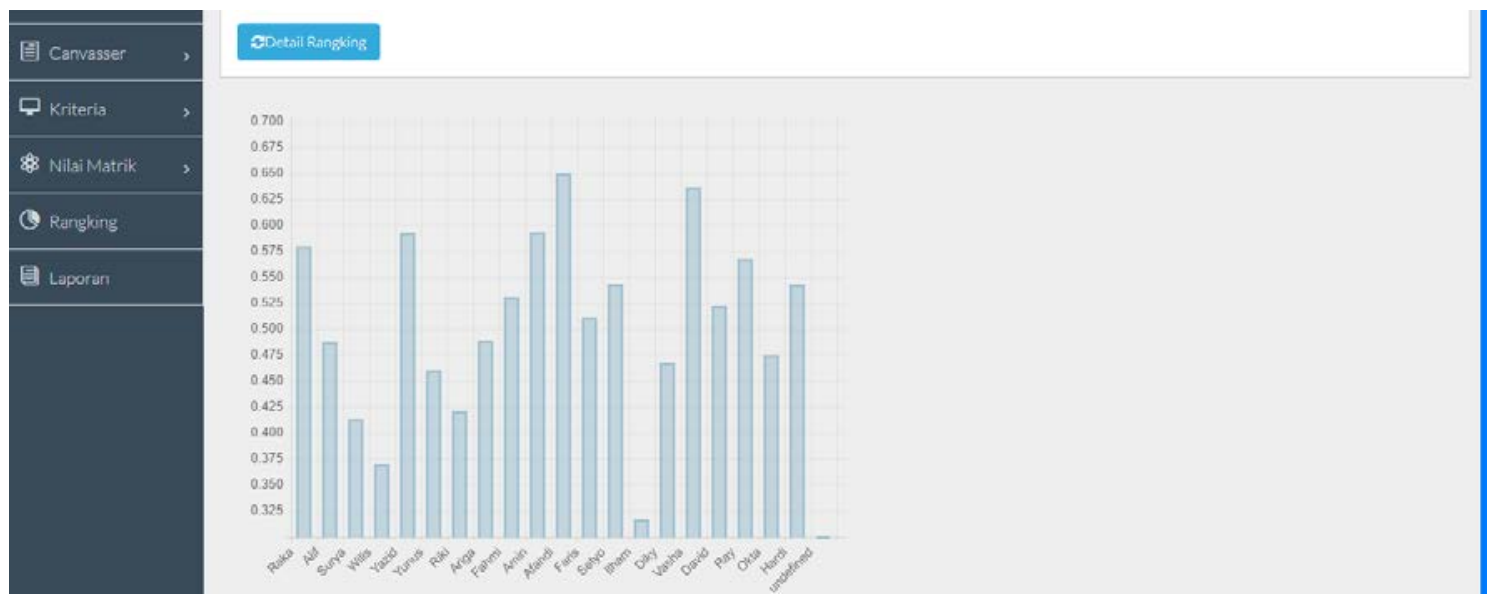

Gambar 6. Halaman Grafik Rangking

Pada Gambar 6 menunjukan grafik dari rangking sales. Sales yang memiliki nilai tertinggi yaitu Afandi dengan nilai akhir 6,50. Perhitungan manual dengan perhitungan sistem menghasilkan hasil yang sama. 


\section{KESIMPULAN}

Setelah melakukan perhitungan sales terbaik dengan menerapkan metode SAW dan TOPSIS maka dapat diperoleh kesimpulan dari penelitian ini adalah sebagai berikut.

1. Sistem pendukung keputusan pemilihan sales terbaik menggunakan 5 kriteria yaitu kriteria penjualan perdana, penjualan voucher, pelayanan, perilaku, dan absesnsi dari sales setiap bulan.

2. Pada hasil nilai preferensi, nilai terbesar yaitu C11 (Afandi) dengan nilai 0,650 sehingga Afandi dikatakan sebagai sales terbaik

3. Perhitungan sistem dengan perhitungan manual sama sehingga sistem dikatakan berhasil diterapkan.

\section{SARAN}

Dalam penelitian ini, saran yang diberikan untuk pengembangan selanjutnya adalah penerapan dengan metode lain agar dapat membandingkan dengan metode SAW TOPSIS dan mencari hasil alternatif terpilih yang lebih maksimal.

\section{DAFTAR PUSTAKA}

[1] Helilintar, R., Winarno, W.W., Al Fatta, H. 2016. Penerapan Metode SAW dan Fuzzy Dalam Sistem Pendukung Keputusan Penerimaan Beasiswa. Citec Jurnal. Vol. 3, No. 2, Hal 89 101.

[2] Mufizar, T. 2015. Sistem Pendukung Keputusan Pemilihan Dosen Berprestasi di STMIK Tasikmalaya Menggunakan Metode Simple Additive Weighting (SAW). CSRID Journal. Vol.7 No.3, Hal. 155-166

[3] Fitriana, A.N., Harliana., Handaru. 2015. Sistem Pendukung Keputusan Untuk Menentukan Prestasi Akademik Siswa dengan Metode TOPSIS. Citec Journal, Vol. 2, No. 2, Hal 153 164.

[4] Kusmiati, H., Octafian, D.T. 2017. Sistem Pendukung Keputusan Pemilihan Ketua Program Studi Berprestasi Menggunakan Metode TOPSIS. CSRID Journal, Vol.9 No.3. Hal 125 - 137.

[5] Kusumadewi, S., Hartati, S., Harjoko, A., Wardoyo, R. 2006. Fuzzy Multi-Attribute Decision Making (FUZZY MADM). Graha Ilmu, Yogyakarta.

[6] Sari, Febrina. 2017. Metode dalam Pengambilan Keputusan. Deepublish. Yogyakarta. 